\title{
Factors associated with the self-care of home-dwelling older people
}

\author{
Päivi Marketta Räsänen ${ }^{1}$, Outi Kanste ${ }^{2}$, Satu Elo ${ }^{1}$, Helvi Kyngäs ${ }^{1,3}$ \\ 1. Institute of Health Sciences, University of Oulu, Oulu, Finland. 2. National Institute for Health and Welfare, Helsinki, \\ Finland. 3. Oulu University Hospital, Oulu, Finland.
}

Correspondence: Päivi Marketta Räsänen. Address: Institute of Health Sciences, University of Oulu, Oulu, Finland. Email: paivi.rasanen@hotmail.fi

Received: September 30, 2013

Accepted: May 3, 2014

Online Published: June 2, 2014

DOI : $10.5430 /$ jnep.v4n8p90

URL: http://dx.doi.org/10.5430/jnep.v4n8p90

\section{Abstract}

Background: The number of older and functionally disabled people in the Finnish population is growing. This means that more and more older people are having to look after themselves at home. Also the need for domiciliary care services is increasing. The aim of this study was to find out if there are connections between the satisfaction with life, self-esteem, functional capacity and the self-care behaviour styles of older people living at home.

Methods: The study was carried out using a descriptive, correlational and cross-sectional design. Data were collected from structured interviews with 180 home-dwelling older people around Finland using a tested instrument. Data were analysed using exploratory factor analyses and correlation coefficients.

Results: A responsible self-care behaviour style had a strong positive correlation to life satisfaction, self-esteem and functional capacity. A formally guided self-care behaviour style had statistically significant links to satisfaction with life and high self-esteem. An independent self-care behaviour style was related to good functional capacity (ADL and IADL) and strong self-esteem. An abandoned self-care behaviour style and factors associated with it were not identified in this study.

Conclusion: This study found connections between different self-care behaviour styles and functional capacity, satisfaction with life as well as self-esteem. Thus, it could be presumed that the identification of self-care behaviour styles and related factors could be utilized by those working in nursing care to understand and support the self-care ability of home-dwelling older people.

\section{Key words}

Self-care, Home-dwelling, Older people, Functional capacity, Satisfaction with life, Self-esteem

\section{Introduction}

The economic recession has led to a shift from institutional care to less expensive domiciliary care in many countries. At the same time, the proportion of ageing people in the population is increasing and thus the number of older and functionally disabled home-dwelling people is also growing. This development challenges the social and healthcare system and relies on the ability of older people to take care of themselves ${ }^{[1,2]}$. 
Older people's self-care is a multifaceted issue that has been defined in multiple ways by different sources as well as being analysed in relation to a number of factors ${ }^{[1,3]}$. Self-care has traditionally been associated with health promotion and is seen as a rational way to behave in order to maintain one's health ${ }^{[4,5]}$. Leenerts et al. (2005) stated that this type of behaviour is learned within a social context early in life, reinforced over a person's lifetime and evolves through cooperation with both professionals and other people. According to Backman (2001), the self-care of older people is "a partly conscious, partly subconscious way to function and live that has formed over the person's life". In addition to the physical manifestations, self-care is also related to the emotional side of life. Backman (2001) found four different self-care types: responsible self-care, formally guided self-care, independent self-care and abandoned self-care. All of these types are influenced by an older person's life and perception of their future. Responsible self-care behaviour implies commitment and responsibility in all the activities of daily living and in caring for health and illness as well as good collaboration with healthcare personnel. People with formally guided self-care behaviour follow medical instructions regularly but uncritically and perform their daily tasks routinely. Independent self-care behaviour comprises unconventional, resolute and single-minded ways to deal with daily activities, health and illness. People who exhibit this type of behaviour are sceptical of healthcare professionals' guidance. It is characteristic for them to cope on their own and to be remarkably independent and determined in their lives. Finally, helplessness and irresponsibility are typical characteristics of people with abandoned self-care behaviour. Older people exhibiting this type of behaviour neglect to take care of themselves. They tend to be bitter and disappointed with their lives ${ }^{[6,7]}$. In this study, Backman's definitions have been used as a theoretical framework to examine the self-care of older people and the factors connected to it.

Many external and internal factors affect the self-care of older people. The external factors include living conditions, various services and social support. Among internal factors, health and an adequate functional ability can be regarded as preconditions for self-care ${ }^{[7-10]}$ with overall health beliefs having a strong correlation with self-care ${ }^{[11]}$. In particular, cognitive functioning and self-care have a significant positive relationship ${ }^{[12]}$. Furthermore, self-care is linked to socio-economic status, level of education, level of social support ${ }^{[13]}$ and the existence of a social network ${ }^{[14]}$. It is also argued that well-being, self-efficacy and motivation for autonomy can empower older people and support self-care ${ }^{[15]}$. Based on the findings of Dale et al. (2012), a good self-care ability is perceived to be closely related to self-care agency, mental health, nutritional status and sense of coherence. According to Backman (2001) and other studies ${ }^{[1,7,9,10]}$, the self-care of older people has been shown to be associated with satisfaction with life, self-esteem and functional capacity.

The aim of this study was to find out if there are connections between the satisfaction with life, self-esteem, functional capacity and the self-care behaviour styles of older people living at home.

\section{Methods}

\subsection{Design}

This study was carried out using a descriptive, correlational and cross-sectional design examining the connections between the self-care behaviour styles of home-dwelling older people and their functional capacity, life satisfaction and selfesteem.

\subsection{Data collection and participants}

The data $(n=180)$ were collected using the self-care of home-dwelling elderly instrument (SCHDE) from a sample of home-dwelling domiciliary care clients aged 74 years or more, living around Finland. The recruitment of people representing each of the four different self-care types as defined in the Backman's theory was carried out using a convenience sample. The interviews were arranged together with domiciliary care personnel in the respondents' homes by the researcher and her assistants ${ }^{[16]}$. The average age of the participants was 81.5 years (range 74-94). Nearly threequarters $(74 \%)$ of the respondents were female and two-thirds or more lived alone (70\%) in detached houses, terraced 
houses, or apartments $(65 \%)$ in cities or communities $(69 \%)$. Only $12 \%$ of the participants had vocational school background or higher education. Of the respondents $88 \%$ had been to no higher than a middle school. Participants' characteristics are shown in more detail in Table 1.

Table 1. Participants' characteristics $(\mathrm{n}=179)$

\begin{tabular}{lll}
\hline Characteristics & Frequencies (n) & Percentages (\%) \\
\hline Sex & 132 & 74 \\
$\quad$ Female & 47 & 26 \\
$\quad$ Male & 123 & 69 \\
$\quad$ Living conditions & 56 & 31 \\
$\quad$ Living in cities or communities & 125 & 70 \\
$\quad$ Living in the countryside & 54 & 30 \\
$\quad$ Widowed or single and living alone & 116 & 65 \\
$\quad$ Living with a spouse or other close person & 63 & 35 \\
$\quad$ Living in a detached house, a terraced house, or an & & \\
$\quad \begin{array}{l}\text { apartment } \\
\text { Living in sheltered housing }\end{array}$ & 21 & 12 \\
Education & 158 & 88 \\
$\quad$ Vocational school or higher education & & 36 \\
$\quad$ Middle school or less education & 65 & 17 \\
Work history & 31 & 47 \\
$\quad$ Worked on farms & 83 & \\
$\quad$ Worked in households & & \\
$\quad$ Worked outside the home & & \\
\hline
\end{tabular}

\subsection{I nstrument}

The SCHDE instrument comprised 77 questions. Nine of them surveyed respondents' background factors and 68 items measured self-care types, functional capacity, satisfaction with life and self-esteem. The instrument consisted of four independent scales and was developed and validated in an earlier study ${ }^{[2,7]}$.

The scale measuring types of self-care was originally developed by Backman and Hentinen (1999) and modified, tested and developed further by Räsänen et al. (2007). It is based on Backman's model for the self-care of home-dwelling elderly ${ }^{[8]}$. The scale contained 42 items. The following are examples of items of this scale: "Different kind of pains and aches rule my life" and "I want to take charge of my medication myself" ${ }^{[2]}$.

The scale of functional capacity was developed based on earlier Finnish studies of older people's functional capacity ${ }^{[3,17]}$. The scale consisted of a total of eleven items measuring activities of daily living (ADL, $n=6$ ) and instrumental activities of daily living (IADL, $\mathrm{n}=5)^{[2,18]}$.

The scale measuring general life satisfaction was based on Diener et al.'s. "Satisfaction With Life Scale" (SWLS) ${ }^{[19]}$. This scale consisted of five items ${ }^{[18]}$ such as: "In most ways my life is close to my ideal" and "I am satisfied with my life" [2].

The scale of self-esteem was originally developed by Rosenberg ${ }^{[20]}$ and translated twice into Finnish by Backman. The Finnish version contained a total of 10 items ${ }^{[18]}$. The following are examples of items measuring self-esteem: "I feel that I have a number of good qualities" and "At times I think I am no good at all" [2].

The various copyright holders of the original instruments have given their permission to use and modify the scales ${ }^{[7,18]}$. The validity and reliability of the instrument were found to be good, based on statistical analyses carried out in earlier studies ${ }^{[2,7]}$. 


\subsection{Ethical issues}

All of the respondents participated in the study voluntarily and gave their informed consent. The respondents received written and oral information informing them that the data would be handled anonymously at all phases of the study. The home care authorities of the participating regions accepted the research plan and gave permission to carry out the study ${ }^{[21]}$.

\subsection{Data analysis}

Statistical analyses were carried out using IMB SPSS Statistics 21.0 software. The data were first analysed using descriptive statistics (frequencies, percentages and means). One questionnaire had to be rejected because of extensive missing data (over half of the items not answered), giving a final total of 179 analysed questionnaires. Since the data were collected through interviews, missing values were rare and random. The total number of missing values was 22 ( 5 self-care behaviour style items, 2 life-satisfaction items, 11 self-esteem items and 4 functional capacity items not answered). In the analyses, missing values were replaced with means in order to make it possible to use multivariate statistics ${ }^{[22]}$. This had no significant effect on the results.

Further data analysis used exploratory factor analyses, sum variables and correlation coefficients. The level of statistical significance was fixed at $p<.05$ in this study ${ }^{[23]}$.

The internal consistency and construct validity of the scales measuring the types of self-care and self-esteem were assessed using exploratory factor analyses for both independent scales. Correlation coefficients of the items had to be 0.30 or more ${ }^{[21]}$ and items with factor loadings $\geq 0.50$ were also included in further analyses. The following rotation criteria were used: eigenvalues greater than 1 , slope of the scree plot, percentage of total variance accounted for and the theoretical background of the phenomenon ${ }^{[23,24]}$.

The sum variables for self-care behaviour styles and self-esteem were formed on the basis of the observed variables specified in the exploratory factor analyses. The sum variable for life satisfaction contained all five items in the scale. The scale for functional capacity was divided into two sum variables: personal activities of daily living (6 items) and instrumental activities of daily living (5 items). The correlation coefficients of these sum variables were used to examine the connections between the self-care behaviour styles, satisfaction with life, self-esteem and functional capacity of the respondents. The internal consistency of both the instrument and the sum variables was ensured using Cronbach's alpha values $^{[21]}$, which are shown in Table 2.

Table 2. Cronbach's alpha values and the number of items measuring the self-care behaviour styles, functional capacity, satisfaction with life and self-esteem of the respondents $(\mathrm{n}=179)$

\begin{tabular}{lll}
\hline Sum variables & Cronbach's alpha & Number of items \\
\hline Responsible self-care behaviour style & 0.78 & 5 \\
Formally guided self-care behaviour style & 0.76 & 4 \\
Independent self-care behaviour style & 0.66 & 3 \\
Personal activities of daily living & 0.89 & 6 \\
Instrumental activities of daily living & 0.89 & 5 \\
Satisfaction with life & 0.81 & 5 \\
High self-esteem & 0.74 & 4 \\
Low self-esteem & 0.76 & 5 \\
\hline
\end{tabular}

\section{Results}

\subsection{Self-care behaviour styles}

In order to identify home-dwelling older persons' different self-care behaviour styles, the scale measuring the types of self-care was divided into three parts: self-care behaviour styles, life experiences and view of the future. 
In the case of self-care behaviour styles, a three-factor solution was found $(\mathrm{n}=179)$, which explained $58.4 \%$ of total variance. The factors were named responsible self-care behaviour style, formally guided self-care behaviour style and independent self-care behaviour style. The abandoned self-care behaviour style was not identified in this study.

\subsection{Connections between the self-care behaviour styles, life satisfaction, self-esteem and functional capacity}

The relationships between the self-care behaviour styles, satisfaction with life, self-esteem and functional capacity of the respondents were explored using correlation coefficients of the sum variables concerning these aspects.

A responsible self-care behaviour style had a strong positive relationship with satisfaction with life, self-esteem and functional capacity. A formally guided self-care behaviour style had statistically significant relationships with satisfaction with life and high self-esteem. An independent self-care behaviour style was related to good functional capacity (personal ADL and IADL) and strong self-esteem. The abandoned self-care behaviour style and factors associated with it were not identified in this study (see Table 3).

Table 3. Correlations between the sum variables of the respondents' self-care behaviour styles, functional capacity, satisfaction with life and self-esteem $(\mathrm{n}=179)$

\begin{tabular}{llllll}
\hline Self-care behaviour style & Personal ADL & IADL & Satisfaction with life & High self-esteem & Low self-esteem \\
\hline $\begin{array}{l}\text { Responsible self-care } \\
\text { behaviour style }\end{array}$ & $0.59^{* *}$ & $0.69^{* *}$ & $0.19^{* *}$ & $0.29^{* *}$ & $-0.39^{* *}$ \\
$\begin{array}{l}\text { Formally guided self-care } \\
\text { behaviour style }\end{array}$ & -0.08 & -0.11 & $0.44^{* *}$ & $0.19^{*}$ & 0.07 \\
$\begin{array}{l}\text { Independent self-care } \\
\text { behaviour style }\end{array}$ & $0.25^{* *}$ & $0.29^{* *}$ & 0.01 & $0.15^{*}$ & $-0.25^{* *}$ \\
\hline
\end{tabular}

Note. Pearson Correlation $(r),{ }^{*} p<.05$ and ${ }^{* *} p<.01$ (2-tailed).

\section{Discussion}

Self-care is a multifaceted issue defined in many different ways and it has been analysed in relation to a number of factors. Many external and internal factors affect the self-care of older subjects. In various studies ${ }^{[7,9,10]}$, the self-care of older people has been found to be related to factors such as life satisfaction, self-esteem and functional capacity. The aim of this study was to find out if there are connections between the satisfaction with life, self-esteem, functional capacity and the self-care behaviour styles of older people living at home.

The limitations of the present study relate to the sampling method. Older people with responsible or formally guided self-care behaviour styles were involved in this study, while there were less people representing independent or abandoned self-care behaviour styles. Thus, the abandoned self-care behaviour style and the factors associated with it could not be identified in this study. Further, most of the respondents did not have opportunity to receive much education and they started work when they were very young. This is partly due to the fact, that all of the respondents were children or teenagers during the Second World War and the depression that followed. The rather small convenience sample means that caution should be taken when generalising the results ${ }^{[24]}$.

Validity and reliability of the study was ensured by exploratory factor analyses and Cronbach's alpha values. The SCHDE instrument was originally tested in an earlier study. The reliability of the instrument was found to be fairly good. The Cronbach's alpha values ranged from 0.49 (low) to respectable $(\alpha=0.72-0.90)^{[2]}$. Further, in this study, the construct validity of the scales measuring self-care types and self-esteem was determined by using separate exploratory factor analyses for both independent scales ${ }^{[16,24]}$. The internal consistency of the instrument and the sum variables were assessed using Cronbach's alpha values, which ranged from satisfactory to high $(\alpha=0.66-0.89)^{[16]}$ (see Table 2). 
Despite differences in the scope and theoretical background, the results of this study are predominantly consistent with previous reports about the self-care of older people ${ }^{[6,7,10,25,26]}$. There are many similarities, especially with regard to the features of responsible, formally guided and independent self-care reported in Backman's (2001) study, which was used as a theoretical framework for this study. A responsible self-care behaviour style is linked to high self-esteem and life satisfaction. People in this category manage independently, although with difficulty, in their activities of daily living. A formally guided self-care behaviour style is linked to the highest satisfaction with life, quite high self-esteem and moderate functional capacity. People with an independent self-care behaviour style are the most independent in their activities of daily living and have quite high self-esteem and moderate life satisfaction. According to Backman (2001), an abandoned self-care behaviour style is connected to helplessness and irresponsibility. These older people do not manage without help in their daily activities and their self-esteem and life satisfaction is mainly low ${ }^{[3,7]}$. All these results are consistent with the findings of the current study, with the exception of those relating to abandoned self-care behaviour style and the factors associated with that, none of which were identified.

Scott and Moneyham (1995) reported that a loss-oriented view of ageing was evident in older people's descriptions of their concerns about the future. This was linked to the fear of increased dependency on others, a sense of insecurity, a sense of being worthless and concern related to healthcare and its resulting costs. On the other hand, feeling valued and respected seemed to build the necessary confidence required for older people to shift the responsibility for their care from others to themselves ${ }^{[25]}$. In addition, Söderhamn (1998) described older people with implicit body images characterised by self-perception as having knowledge about their actual health problems and knowing how to deal with them ${ }^{[26]}$.

The results of this study also bear some similarities to a Slovenian study about the self-care of home-dwelling older people. According to Zeleznik (2007), older people who were able to take care of themselves had good functional capacity and good family relationships. They also accepted the future and were satisfied with their lives. In contrast, people with an abandoned self-care behaviour style did not take care of themselves and were not satisfied with their way of life ${ }^{[10]}$. Further, Lauder's (1999) findings about self-neglecting people are, to some extent, consistent with the features of independent and abandoned self-care. Self-neglect was conceptualised as the failure to engage in adequate actions necessary for health and well-being. Self-negligent people might be either fully independent or fully dependent for ADL functions ${ }^{[27]}$.

Self-care is part of a home-dwelling older person's life. It is connected to life satisfaction, self-esteem, functional capacity and many other factors. Knowledge and identification of the self-care behaviour styles and connected factors could be utilized by those working in nursing care to understand and support the self-care ability of home-dwelling older people.

\section{References}

[1] Dale B, Söderhamn U, Söderhamn O. Self-care ability among home-dwelling older people in rural areas in southern Norway. Scandinavian Journal of Caring Sciences. 2012; 26: 113-22. http://dx.doi.org/10.1111/j.1471-6712.2011.00917.x

[2] Räsänen P, Backman K, Kyngäs H. Development of an instrument to test the middle-range theory for the self-care of home-dwelling elderly. Scandinavian Journal of Caring Sciences. 2007; 21: 397-405.

http://dx.doi.org/10.1111/j.1471-6712.2007.00468.x

[3] Backman K, Hentinen M. Factors associated with self-care of home-dwelling elderly. Scandinavian Journal of caring Sciences. 2001; 15: 195-202. http://dx.doi.org/10.1046/j.1471-6712.2001.00007.x

[4] Orem DE. Nursing. Concepts of Practice. 5th edn. St Louis, MO: Mosby Year Book; 1995.

[5] Denyes MS, Orem DE, SozWiss G. Self-care: a foundational science. Nursing Science Quarterly. 2001; $14: 48-54$. http://dx.doi.org/10.1177/089431840101400113

[6] Leenerts MH, Teel CS, Pendleton MK. Building a model of self-care for health promotion in aging. Journal of Nursing Scholarship. 2002; 34: 355-61. PMID:12501739 http://dx.doi.org/10.1111/j.1547-5069.2002.00355.x

[7] Backman K. Kotona asuvien ikääntyvien itsestä huolenpito (Self-care of Home-dwelling Elderly). PhD thesis. University of Oulu, Department of Nursing and Health Administration, 2001. Available from:

http://herkules.oulu.fi/isbn9514259033/isbn9514259033.pdf

Published by Sciedu Press 
[8] Backman K, Hentinen M. Model for the self-care of home-dwelling elderly. Journal of Advanced Nursing. $1999 ; 30: 564-72$. PMID:10499212 http://dx.doi.org/10.1046/j.1365-2648.1999.01125.x

[9] Fagerström C, Holst G, Hallberg IR. Feeling hindered by health problems and functional capacity at 60 years and above. Archives of Gerontology and Geriatrics. 2007; 44: 181-201. PMID:16820228 http://dx.doi.org/10.1016/j.archger.2006.03.004

[10] Zeleznik D. Self-care of the home-dwelling elderly people living in Slovenia. PhD thesis. University of Oulu, Department of Nursing and Health Administration, 2007. Available from: http://herkules.oulu.fi/isbn9789514286377/isbn9789514286377.pdf

[11] Klainin P, Ouannapiruk L. A meta-analysis of self-care behavior research on elders in Thailand: an update. Nursing Science Quarterly. 2010; 23: 156-63. PMID:20167710 http://dx.doi.org/10.1177/0894318410362788

[12] Tao H, Ellenbecker CH, Chen J, Zhan L, Dalton J. The influence of social environmental factors on rehospitalization among patients receiving home health care services. Advances in Nursing Science. 2012; 35: 346-58. PMID:23107991 http://dx.doi.org/10.1097/ANS.0b013e318271d2ad

[13] Toye C, White K, Rooksby K. Fatigue in frail elderly people. International Journal of Palliative Nursing. 2006 ; 12 : 202-8. PMID:16835559

[14] Dale B, Saevareid HI, Kirkevold M, Söderhamn O. Older home nursing patients' perception of social provisions and received care. Scandinavian Journal of Caring Sciences. 2010; 24: 523-32. PMID:20409065 http://dx.doi.org/10.1111/j.1471-6712.2009.00744.x

[15] Borg C, Hallberg IR, Blomqvist K. Life satisfaction among older people (65+) with reduced self-care capacity: the relationship to social, health and financial aspects. Journal of Clinical Nursing. 2006; 15: 607-18. http://dx.doi.org/10.1111/j.1365-2702.2006.01375.x http://dx.doi.org/10.1111/j.1365-2702.2006.01375.x

[16] Burns N, Grove SK. The Practice of Nursing Research, 7th Edition: Appraisal, Synthesis, and Generation of Evidence. St. Louis: Saunders, 2012.

[17] Winblad I. 75 vuotta täyttäneiden terveydentila ja hoito maaseudulla. (Health status and care of old people aged 75 years and over in a rural area). PhD thesis. University of Oulu: Acta Universitatis Ouluensis Series D Medica 166, 1988.

[18] Karjalainen E, Kivelä S-L. Iäkkäiden palvelutaloasukkaiden terveys, toimintakyky ja elämänlaatu. (Health, abilities and quality of life of the elderly living in sheltered homes).University of Oulu, Kansanterveystieteen ja yleislääketieteen laitos, 1995.

[19] Diener E, Emmons RA, Larsen RJ, Griffin S. The satisfaction with life scale. J Pers Assess. 1985; 49: 71-5. PMID:16367493 http://dx.doi.org/10.1207/s15327752jpa4901_13

[20] Rosenberg M. Society and the adolescent self-image. Princeton, New Jersey: Princeton University Press, 1965.

[21] Polit DF, Beck CT. Nursing Research. Principles and Methods. Philadelphia, PA: Lippincott, Williams \& Wilkins; 2012.

[22] Metsämuuronen J. Monimuuttujamenetelmien perusteet. (The basics of multivariate statistics). Metodologia-sarja 7. Helsinki: Methelp Ky; 2008.

[23] Nummenmaa L. Käyttäytymistieteiden tilastolliset menetelmät. (Statistical methods of behavioral sciences). Helsinki: Tammi; 2009.

[24] Gillis A, Jackson W. Research for Nurses: Methods and Interpretation. Philadelphia, PA: F.A. Davis Company; 2001.

[25] Scott CB, Moneyham L. Perceptions of senior residents about a community-based nursing center. Image - the Journal of Nursing Scholarship. 1995; 27: 181-86. http://dx.doi.org/10.1111/j.1547-5069.1995.tb00856.x

[26] Söderhamn O. Self-care ability in a group of elderly Swedish people: a phenomenological study. Journal of Advanced Nursing 1998; 28: 745-53. Available from: http://onlinelibrary.wiley.com/doi/10.1111/j.1365-2648.1998x.00705.x http://dx.doi.org/10.1111/j.1365-2648.1998x.00705.x

[27] Lauder W. A survey of self-neglect in patients living in the community. Journal of Clinical Nursing. 1999; 8: 95-102. http://dx.doi.org/10.1046/j.1365-2702.1999.00231.x 